\title{
TEACHER-PARENT COMMUNICATION PATTERNS ON THE STUDENTS' CHARACTER BUILDING IN MTSN 1 BONE
}

\author{
A. Mustika Abidin1, Musdalifa Gaffar² \\ 1,2UIN Alauddin Makassar \\ 1,2Jalan H.M. Yasin Limpo No.36 Samata-Gowa \\ Email: a.mustika@uin-alauddin.ac.id ${ }^{1}$, gaffarmusdalifah@gmail.com²
}

\begin{abstract}
:
This research aims at finding the teacher-parent communication patterns on the students' character building in MTsN 1 Bone. This research type is descriptive qualitative research which applied sociological approach. The data sources are the teachers of grade VII moral religion and the parents of 6 students. The methods of the data collection used are observation, interview, and documentation. The data analysis techniques used are data reduction, data presentation, and conclusion drawing. The research results show that there are three teacher-parent communication patterns namely by using or applying verbal communication, nonverbal communication, and interpersonal communication. With those communication patterns, it is expected that it can help in the students' character building and support the formal and informal education processes.
\end{abstract}

\begin{abstract}
Abstrak:
Penelitian ini bertujuan untuk menemukan pola komunikasi guru dengan orang tua dalam pembentukan karakter siswa di MTsN 1 Bone. Jenis penelitian ini adalah penelitian kualitatif deskriptif dengan menggunakan pendekatan sosiologis. Sumber data adalah guru akidah akhlak kelas VII dan orang tua siswa sebanyak 6 orang. Metode pengumpulan data yang digunakan yaitu observasi, wawancara, dan dokumentasi. Teknik pengolahan data yang digunakan yaitu reduksi data, penyajian data, dan penarikan kesimpulan. Hasil penelitian menunjukkan bahwa terdapat tiga pola komunikasi guru dengan orang tua yaitu dengan menggunakan atau menerapkan komunikasi secara verbal, komunikasi non-verbal, dan komunikasi antar pribadi. Dengan adanya pola komunikasi ini diharapkan dapat membantu dalam pembentukan karakter siswa dan menunjang proses pendidikan formal dan pendidikan informal.
\end{abstract}

Keywords:

Communication Patterns, Character Building, MTsN 1 Bone

How to Cite: Abidin, A. M. \& Gaffar, M. (2020). Teacher-Parent Communication Patterns on The Students' Character Building in MTsN 1 Bone. Lentera Pendidikan : Jurnal Ilmu Tarbiyah dan Keguruan, 23(2), 285-294. https://doi.org/10.24252/lp.2020v23n2i8.

\section{INTRODUCTION}

Character is essential in the life of the nation and the state because without the character, it will lead to the loss of the next generation of the nation. The character also serves as a mobilizer and strength so that this nation will not be tossed around, so it can be understood that one of the stages in order to build character is through the 
educational process so that every human has a strong character, dignified, and has great civilitation (Wibowo, 2012).

Lickona (2012) believes that education has two great goals, helping children become smart and helping them to be a good one as one of the purposes of education is to build children character.

The purpose of education not only gives birth to intelligent people, but also creates a person of strong character. As Martin Luther King said in Muslich, that: "intelligence plus character that is the goal of true education" (Muslich, 2011: 75). It is understandable that intelligence is not the main thing in realizing a real education, but helping children become good is also a priority so that cooperation and communication from various parties are needed.

One of the parties who is responsible in the character building of the students is the teacher. In addition, to be an academic teacher and educator, the teachers also play an important role as educators of character, morals, and culture for their students. In addition to teachers, the family role is also needed in character building because the family is the first educational place for a child so that with a harmonious relationship between families, it will facilitate the educational process of a child/student. Based on it, the teachers and the parents communication is an effort to establish the character because without communication between teachers and parents, the character will not be formed in the students.

Every human being needs communication because the communication is the basic human activity in an interaction. In addition, the humans are social beings who cannot live alone. The communication patterns are derived from two words, namely pattern and communication. The pattern can be interpreted as a way or form to indicate something can happen whereas communication comes from the word communicate which means to participate, notify, become a joint property so that conceptually the meaning of communication contains the understanding of telling (spreading) news, knowledge, thoughts, values with the intent to upload participation so that the things that are told become joint property (Pawif, 2010). The communication is a process of exchanging ideas, messages, and social interactions so that through a communication, the humans can get to know each other better, establish relationships, foster cooperation, influence each other, exchange ideas and opinions (Nafrion, 2016: 1). Thus, communication patterns are the way of a person both individuals and groups in the process of sending and receiving messages appropriately so that the message in question can be conveyed and easy to understand. Humans are individual beings and social beings. As a social being, it can be intended that a human cannot be separated from other individuals because naturally a human always lives with other humans and there will be various forms of communication or situations so that in this kind of life there is interaction.

Mulyana (2017) defines patterns or forms of communication which consist of: (1) verbal communication, i.e. communication using symbols or words either expressed orally or in writing. Oral communication is a process of interacting orally using speech and being heard so as to influence behaviors such as over the phone, radio, television, etc. 
Writing communication is a communication in the form of symbols such as using letters, notes/memos, pictures and reports; (2) Non-verbal communication, i.e. exchange of messages without the use of spoken or written words, e.g. non-verbal communication i.e. using gestures and attitudes of the body, eye contact, and facial expressions; and (3) Interpersonal communication, i.e. the delivery of messages from a person and it is received by another person, so as to generate direct feedback because this communication is done face-to-face.

Mulyasa (2013) defines the establishment of process, way, act of forming while character is defined as behavior based on values based on religious norms, culture, law/constitution, customs, and aesthetics, whereas according to Fitri (2012) the character is values related to the One True Allah Swt, himself, fellow human beings, environment and nationalities that manifest in the thoughts, attitudes, feelings, words, and deeds based on religious norms, laws, manners, culture and customs. Thus, the character building is a process that is carried out in the life to form basic values/characters in a person to build the personality of the person, both the value of the character that must exist between man and his Allah Swt, fellow humans, the environment and one's personal self.

Referencing some of the above descriptions, it is understandable that communication between the teachers and the parents is one of the most decisive elements in the students' character building. The teachers and the parents basically have the same goal of educating, guiding, and nurturing a child to be a person who has good character so that it can be beneficial for him or others. In order to realize these expectations, of course both teachers and parents must have and apply good communication each other. Good communication between teachers and parents is needed because these two parties often come face-to-face with the students or the children. If the communication between the teachers and the parents is reduced or nonexistent, then the purpose of education is feared not to be going well and will certainly have an impact on the character of the children.

There are several research findings related to the communication patterns, which show that the communication patterns applied by the teachers in the process of character building of the children is a communication pattern as transactions (communication of many directions) i.e. the teachers try to direct the children rationally, orient to the problems faced, appreciate communication by giving and receiving, and explain the rational reasons underlying each request or discipline (Bagus \& Dewi, 2018). In addition, the results of the study (Sandi et al., 2017) show that the communication patterns applied by teachers in shaping the students' characters are communication patterns in many directions because this communication pattern is more supportive in the teaching learning process.

As in MTsN 1 Bone, character building of the students is crucial, so that it is necessary to have a communication between the teacher and the parents. Through the communication patterns verbally, non-verbally, and interpersonally, the characters of the students can be formed well. 


\section{RESEARCH METHOD}

This research is a qualitative descriptive study. Sukmadinata (2011: 73) states that qualitative descriptive research is used to describe existing phenomena, both natural, which pay more attention to characteristics, quality, and linkages among the activities. In addition, this type of qualitative descriptive research describes the conditions as they are, without giving treatment or manipulation to the variables studied so that the data obtained are as they are and emphasizes the meaning of the results. Therefore, this qualitative descriptive research is used to describe and interprete the teacher-parent communication patterns in the character building. This research was conducted at MTsN 1 Bone at Sukawati Street District of Tanate Riattang Manurungnge Village, Bone Regency. This research used a sociological approach. Nata (2014) states that sociological approach is a way or method of analyzing research objects that appear, blaring, and becoming reality in life. In addition, the sociological approach can also be understood as a science that learns to live together in the society and investigates the bonds among the humans, so this approach is used by the researchers to establish communication and interact with teachers and the students' parents in order to know the teacher-parents communication patterns on the students' character building in MTsN 1 Bone. The data sources in this study are divided into two primary data sources consisting of grade VII teachers and parents of 6 students. The secondary data sources are obtained from the information media and other references, documentation and the data from the schools. The method of data collection used is to make observations, interviews, and documentation. The research instruments used are interview, observation guidelines, and documentation. The data processing and analysis techniques used are data reduction by summarizing and selecting important things and then presenting the data in the form of a brief description and finally draw conclusions based on the results of interviews, observations, and documentation.

\section{RESULTS AND DISCUSSION}

This research aims to reveal out the teacher-parent communication patterns on the students' character building in MTsN 1 Bone. Based on the results of the research, the communication patterns used by the teachers and the parents on the students' character building were through verbal, non-verbal, and interpersonal communication. The communication patterns refer to as the results of this study which include:

\section{Verbal Communication}

Verbal communication is to use words that represent various aspects of reality that exist in a person. The words as such expressions are packaged in two ways, namely verbally and non-verbally or in writing form (Suranto, 2010).

Kusumawati (2016) stated that verbal communication is a communication that uses both oral and written words. This communication is most widely used in human relationships in daily lives. Through words, humans express their feelings, emotions, thoughts, and information so that the others can understand each other. 
Verbal communication is the delivery of communication by composing words into a pattern that has meaning or meaning in both written and oral form. This verbal communication is one of the important aspects of the character education process because the quality of communication that is intertwined between the teachers and the students in instilling character values will affect the characters of the students (Zurna et al., 2018).

Referencing the above description, it can be understood that verbal communication is a communication that is easy to understand because the teachers interact with the students' parents by using language, gentle words both verbally and in writing.

Based on the results of the observations, the grade VII teachers applied verbal communication namely communicating orally and in writing to the students' parents. The interview result with the teachers shows that shaping the character through verbal communication is to meet directly with the students' parents. Face-to-face with the students' parents makes it easier for the teachers to discuss the students' development in the school. In addition to meeting in person, this verbal communication is also done by writing progress notes of the students in the connecting book, communication via phone, whatsapp, and other applications.

The interview results with the students' parents explain that: (1) to find out the characters of the students, the parents communicate orally with the teachers of moral beliefs when picking up their children at the school. Although in a short period of time, this communication can provide information related to the students' characters especially while they are in the school; (2) the pattern of communication that is established between the teachers and the parents is to have verbal communication verbally by phone or video call because this will help to know the development of the students both intellectually and their attitudes; (3) the pattern or the form of the verbal communication that is done between the teachers and the students' parents is through the connecting book because with the connecting book, the parents can see the notes written by the teachers regarding the characters of their children; (4) the communication that is intertwined i.e. meeting with the teachers in the school and asking about the attitudes/characters of the their children when attending the learning in the classroom or when they are outside the classroom; (5) the verbal communication between the teachers and the parents is through the connecting book. In this book, the parents can know the intellectual development and characters of their children when they are in the school; and (6) the pattern of communication that is carried out is to meet directly with the teachers. When meeting, the teachers briefly convey the students' characters when they are at the school by using language that is easy to understand.

Based on the results of the research above, it is inferred that through verbal communication between the teachers and the students' parents both verbally and in the written form such as meeting, using the telephone, video calls, notes/connecting books, and so forth, the good characters can be possessed by the students. 


\section{Non- Verbal Communication}

According to Barata in Solihin (2015), non-verbal communication is a communication expressed through objects in every other category (the object language), communication using motion (gesture) as a signal (sign language), as well as communication through actions or body movements (action language). Pratama \& Priyantoro (2017) stated that non-verbal communication covers a wide range of activities and behavior including gestures, eye contact, closeness to other people (these activities are popularly called "body language").

Non-verbal communication is a communication whose message is packaged in a form without words. In daily lives, non-verbal communication is much more widely used than verbal communication. In communicating, almost simultaneously non-verbal communication is also used. Therefore, non-verbal communication is constant and always exists. Non-verbal communication is more honest in expressing what will be expressed because it is spontaneous. In another sense, non-verbal communication can take the form of symbols such as gestures, colors, facial expressions, and so forth (Kusumawati, 2016).

Non-verbal communication is just as important as verbal communication because the two work together in the communication processes. With the existence of non-verbal communication, it can provide emphasis, repetition, complement and replace verbal communication, so that it is easier to interpret the meaning. Non-verbal communication is the creation and exchange of messages without the use of words such as communication that uses gestures, body attitudes, eye contact, facial expressions, proximity of distance and touching (Mulyana, 2017).

Referencing the above description, it can be understood that non verbal communication is the exchange of messages without using spoken or written words. Based on the results of the observations, grade VII teachers applied non-verbal communication such as staring, giving smiles, waving hands, and using head gestures towards the students' parents. The interview results with the teachers indicate that in addition to communicate verbally with the students' parents, the teachers also use nonverbal communication such as looking at the students' parents when picking up their children at the school, waving, and giving a smile to the students' parents. This communication is indeed without the use of words but it complements verbal communication and provides benefits for the closeness between the teachers and the students' parents. The interview results with the students' parents explain that: (1) although the parents not always communicate with the teachers when picking up their children at the school, the teachers sometimes see/stare and give a smile; (2) the pattern of non-verbal communication that is intertwined between the teachers and the parents that is the teachers give a smile when the parents pick up their children at the school and it provides warmth even without communicating verbally; (3) when picking the children up from the school, the teachers sometimes wave and give a smile so that the parents feel a closeness to the teachers; (4) non-verbal communication is happened through some activities such as staring, giving a nod and a smile so that the harmony between the 
teachers and the students' parents can be intertwined; (5) when picking up the children at the school, the teachers sometimes give a smile, so the parents feel positive about the children's development at the school; and (6) in addition to verbal communication, both verbal and written, the teachers also give a smile when the parents pick up the children at the school. Although the teachers and the students' parents do not talk each other, this non-verbal communication provides good benefits especially to the parents.

Based on the results of the above research, it can be inferred that the teacherparent communication patterns on the students' character building by applying nonverbal communication are like communication done with gestures or body language without using words such as staring, waving and giving a smile. This non-verbal communication is useful for sending meaning, expressing emotions, and influencing others so that this communication is precisely done on the teacher-parent communication patterns on the students' character building.

\section{Interpersonal Communication}

Interpersonal communication emphasizes on communication of dialogue between people. Everyone involved in this communication doubles down, i.e. each becomes a speaker and listener alternately. This communication has an advantage over other communication patterns because the interpersonal communication has a deeper emotional connection between the communicator and the communicant (Hidayatulloh, 2018).

According to Soyomukti (2012), interpersonal communication is a process of relationships created between an individual (who acts as a communicator) and another individual (who acts as a communicant). A communicator will deliver his message to the communicant so that the communicant will receive the message face-to-face and then get a response or feedback directly.

Interpersonal communication is a communication process that takes place between two or more people face-to-face where the sender delivers the message directly and the recipient of the message can respond directly to the message. This interpersonal communication is not only a series of stimulus-responses, but it is also a process of receiving and delivering responses that have been processed by each party. In order for interpersonal communication to produce effective relationships, it is necessary to be opened, trusting, supportive, and respectful of each other so that the goals that are to be achieved can be realized properly (Zulqarnaen, 2016).

Referencing the above description, it can be understood that interpersonal communication is the delivery of messages from a person and it is received by another person then generates direct feedback because these communications are done by faceto-face.

Based on the observation results, the teachers applied interpersonal communication such as discipline coaching, exemplary coaching, and habituation coaching. The interview results with the teachers explain the interpersonal communication such as: (1) the discipline coaching; as a teacher of morals so that the students' characters can be better, of course, communicate with the students' parents so 
that they teach discipline to the children at home such as getting up early on time, doing prayers, and memorizing short surahs, and other things because the teachers are not able to monitor the children at home. However, when the children are in the school, the teachers are responsible for teaching discipline to them. With the pattern of interpersonal communication in the development of this discipline, the students' character building can be realized well. The interview results with the teachers are then reinforced by the interview results with one of the parents of the students stating that as a parent, of course, it is expected that the children have a good behavior or character. In order to make it happen, when there is a free time as a parent meet with the teacher and talk about the character especially the discipline of the children when they are in the school. This interpersonal communication provides an understanding so that the teachers' communication with the parents remains intertwined so that the character of the students in terms of discipline can be formed properly; (2) exemplary coaching; in order to make the students have good character, especially in the terms of examples, then the teachers must first set a good example to the students. In addition, the teachers also communicate with the parents in order to set a good example for the children when they are at home. With this communication, the children's character, especially in fostering exemplary, can be well formed. The interview results with the teachers are then reinforced by the interview results with one of the students' parents who stated that to know the children's development, it can be known when the parents meet with the teachers for the moment's conversation. In the meeting, the teachers conveyed the character of the children especially in the terms of giving example while in the school. In addition, the teachers also conveyed about the need for parental participation in shaping the students' characters in the terms of giving example so that the character that has been formed in the school remains while the children are at home; and (3) habituation coaching; as the teachers of moral beliefs, of course, directing the students' characters in the terms of habituation can be formed. To make this character of habituation to be easily formed or applied, the teachers need to establish communication with the students' parents in order to cooperate in the formation of the students' habituation characters such as directing the students to get used to thinking, behaving and acting in accordance with the guidance of the Islamic teachings and getting used to doing activities regularly and continuously. The interview results with the teachers are then reinforced by the interview results with one of the students' parents stating that the interpersonal communication with the teachers is very helpful to teach the students to get used to doing good things regularly in life. With this communication, the character of the students in terms of habituation can be monitored and formed properly.

\section{CONCLUSION}

Based on the results, it can be concluded that the teacher-parent communication patterns on the students' character building in MTsN 1 Bone is carried out well by applying three communication patterns namely the pattern of verbal communication, non-verbal communication, and interpersonal communication. 
The pattern of verbal communication applied by the teachers with the parents on the students' character building is oral and written communication. The oral communication is such as using a phone, video call, and so forth, while communication in writing is such as using notes/connecting books. With the verbal communication both oral and written, it helps the teachers and the parents to express feelings, emotions, intentions, information, exchanges of feelings and thoughts in shaping the students' characters.

The patterns of non-verbal communication performed by the teachers with the parents on the students' character building are such as both teachers and parents use sign language or body language when meeting like staring, waving and giving smiles. This communication is useful for sending meaning, expressing emotions, and influencing others. A person can draw a conclusion about feelings, both pleasure, hate, love, and various other feelings that are shown by other people through non-verbal communication.

The patterns of interpersonal communication performed by the teachers with the parents on the character building are such as the teacher communicating face-to-face with the students' parents regarding discipline coaching, exemplary coaching, and habituation coaching so that the character of the students can be formed better. When this interpersonal communication takes place there is feedback or sharing between the two parties, namely the teachers and the parents so that it can be understood that communication and time to exchange ideas for the teachers and the parents must be a priority in the character building and it must be supported by the teachers who have the requirements for being a good communicator, namely having credibility and skills in communicating, having extensive knowledge, having a good attitude towards the communicant and having attractiveness in the sense that the communicator has the ability to change attitudes or add knowledge to the communicant.

Thus, it can be inferred that the communication between the teachers and the parents is one of the most decisive elements on the students' charatcer building. The teachers and the parents basically have the same goal of educating, guiding, and nurturing the students to be a person who has good characters so that it can be beneficial for him or others. In order to realize these expectations, of course both teachers and parents must have and apply good communication each other. Good communication between teachers and parents is needed because these two parties often come face-toface with the students or children. If the communication between the teachers and the parents is reduced or nonexistent, then the purpose of education is feared not to be going well and will certainly have an impact on the students' character.

\section{REFERENCES}

Bagus, A. A. G., \& Dewi, E. (2018). Pola Komunikasi Guru dan Murid dalam Proses Pembentukan Karakter Anak di PAUD Pancaran Berkat Baturiti Tabanan Bali. Jurnal Ilmu Komunikasi, Fakultas Ilmu Komunikasi Universitas Dwijendra, 30-40. http://ejournal.undwi.ac.id/index.php/ilkom/article/view/632. 
Fitri, A. Z. (2012). Pendidikan Karakter Berbasis Nilai dan Etika di Sekolah. Yogyakarta: Ar-Ruzz Media.

Hidayatulloh, R. A. (2018). Pola Komunikasi Antarpribadi antara Guru dan Murid Pada Proses Pembentukan Karakter Budaya Sunda Sejak Remaja Awal di SMP YAS Kota Bandung. $\quad$ https://elib.unikom.ac.id/files/disk1/797/jbptunikompp-gdlrizkyachma-39812-9-unikom_4-i.pdf.

Kusumawati, T. I. (2016). Komunikasi Verbal dan Nonverbal. Al-Irsyad: Jurnal Pendidikan Dan Konseling, 6(2), 83-98. http://jurnal.uinsu.ac.id/index.php/alirsyad/article/view/6618.

Lickona, T. T. J. A. W. (2012). Education for Character: How Our School Can Teach Respect and Responsibility. Jakarta: Bumi Aksara.

Mulyana, D. (2017). Ilmu Komunikasi Suatu Pengantar. Bandung: PT Remaja Rosdakarya.

Mulyasa. (2013). Manajemen Pendidikan Karakter. Jakarta: Bumi Aksara.

Muslich, M. (2011). Pendidikan Karakter: Menjawab Tantangan Krisis Multidimensional. Jakarta: PT Bumi Aksra.

Nafrion. (2016). Komunikasi Pendidikan: Penerapan Teori dan Konsep Komunikasi dalam Pembelajaran. Jakarta: Kencana.

Nata, A. (2014). Sosiologi Pendidikan Islam. Jakarta: Rajawali Pers.

Pawif, M. Y. (2010). Komunikasi Instruksional Teori dan Praktik. Jakarta: Bumi Aksara.

Pratama, L. R., \& Priyantoro, D. E. (2017). Urgensi Pengembangan Bahasa Verbal dan Non Verbal Anak Usia Dini. Annual Conference on Islamic Early Childhood Education, 2, 245-256.

suka.ac.id/index.php/aciece/article/view/74/76.

http://conference.uin-

Sandi, A., Abdullah, M. Z., \& Ridwan, H. (2017). Pola Komunikasi Guru dalam Membentuk Karakter Siswa di SMK Negeri 1 Kendari. Jurnal Ilmu Kamunikasi UHO, 2(1), 1-14. http://ojs.uho.ac.id/index.php/KOMUNIKASI/article/view/1875/1316.

Solihin, O. (2015). Makna Komunikasi Non Verbal dalam Tradisi Sarungan di Pondok Pesantren Tradisional di Kota Bandung. JIPSI-Jurnal Ilmu Politik Dan Komunikasi UNIKOM, 4, 1-12. https://repository.unikom.ac.id/30689/.

Soyomukti, N. (2012). Pengantar Ilmu Komunikasi. Yogyakarta: Ar-Ruzz Media.

Sukmadinata, N. S. (2011). Metode Penelitian Pendidikan. Bandung: PT Remaja Rosdakarya.

Suranto. (2010). Komunikasi Sosial Budaya. Yogyakarta: Graha Ilmu.

Wibowo, A. (2012). Pendidikan Karakter: Strategi Membangun Karakter Bangsa Berperadaban. Yogyakarta: Pustaka Pelajar.

Zulqarnaen, W. (2016). Komunikasi Antarpribadi Ustadz dan Santri dalam Pembentukan Karakter Santri. Universitas Islam Negeri Syarif Hidayatullah, Jakarta.

Zurna, H. P., Fatmariza, \& Isnarmi. (2018). Penanaman Nilai-Nilai Karakter Melalui Komunikasi Verbal di Sekolah Dasar. Journal of Civic Education, 1(2), 189-196. https://doi.org/10.24036/jce.v1i2.182. 